\title{
Business cycle synchronisation in EMU: Can fiscal policy bring member-countries closer?
}

\author{
Stavros Degiannakis ${ }^{1,2}$, David Duffy ${ }^{3}$, George Filis $^{4 *}$, Alexandra Livada ${ }^{5}$ \\ ${ }^{1}$ Department of Economics and Regional Development, Panteion University of Social and \\ Political Sciences, 136 Syngrou Avenue, GR17671, Athens, Greece. \\ ${ }^{2}$ Postgraduate Department of Business Administration, Hellenic Open University, Greece. \\ ${ }^{3}$ Department of Accounting, Finance and Economics, University of Ulster, \\ Shore Road, Newtownabbey, BT37 0QB, UK. \\ ${ }^{4}$ Department of Accounting, Finance and Economics, Bournemouth University, \\ Executive Business Centre, 89 Holdenhurst Road, BH8 8EB, Bournemouth, UK. \\ ${ }^{5}$ Department of Statistics, Athens University of Economics and Business, \\ 76 Patission str., Athens, 10 434, Greece.
}

*Corresponding author: George Filis, email: gfilis@bournemouth.ac.uk, tel: 0044 (0) 1202 968739, fax: 0044 (0) 1202968833

\begin{abstract}
The present study adds to the literature on the impact of fiscal policy on business cycle synchronisation. Specifically, it investigates the effects of fiscal policy on business cycle synchronisation between the 10 EMU member-countries and the aggregate EMU12-wide business cycle, using a time-varying framework. The findings suggest that fiscal policy has important effects on business cycle synchronisation for all 10 EMU countries. Hence, fiscal policy is shown to have the potential to be supportive of macroeconomic stabilisation in the Eurozone. However the evidence reveals that none of the countries under examination consistently use fiscal policy to promote business cycle synchronisation.
\end{abstract}

Keywords: Time varying correlation, EMU business cycle, business cycle synchronisation, fiscal policy, Diag-BEKK model.

JEL: C32, E32, E62, O52. 


\section{Introduction}

Since the launch of the Euro currency in 1999, European Monetary Union (EMU) has experienced a short but turbulent history. The knock on effects of the 2007 Economic and Financial Crisis has led to an "existential" crisis for the Eurozone. The root cause of the current difficulties for the Eurozone lies in the inherent contradiction between a single, supra-national currency and the maintenance of nation based fiscal policies and financial regulation (see, Lane, 2012 and Shambaugh, 2012 for a review).

To ensure that supra-national ("one size fits all") monetary policies are appropriate in individual national economies and thus ensuring that the union-wide monetary policy can effectively substitute national monetary policies, business cycles synchronisation is of paramount importance. If business cycles are not synchronised, national fiscal policies take on an additional importance as a tool for macroeconomic stabilisation policy.

The importance of business cycle synchronisation for the operation of a common currency area has been highlighted in the seminal works on Optimum Currency Area theory (OCA) by Kennen (1969), McKinnon (1963), and Mundell (1961), as well as, in more recent contributions by Furceri and Karras (2008) and Alesina and Barro (2002). Indeed, business cycle synchronisation is regarded as a pre-requisite for the effective functioning of a monetary union (Alesina and Barro, 2002), and the very survival of a monetary union depends on the commonality of business cycle fluctuations (see Bergman, 2006) ${ }^{1}$.

Business cycle synchronisation refers to the level of co-movement of the boom-bust economic phases of the member-countries over time ${ }^{2}$. It must be emphasised that business cycle synchronisation does not necessarily mean convergence in economic growth rates (see, Degiannakis et al., 2014). Convergence refers to the catch-up effect among countries' growth rates, as opposed to synchronisation which refers to the co-movements of the countries' growth rates (Crowley and Schultz, 2010).

To elaborate further, we argue that in a monetary union with synchronised business cycles among its member-countries, the common monetary policy can be effectively used as a

\footnotetext{
${ }^{1}$ Burns and Mitchell (1946, p.3) defines a business cycle as follows:

"A cycle consists of expansions occurring at about the same time in many economic activities, followed by similarly general recessions, contractions, and revivals which merge into the expansion phase of the next cycle; this sequence of changes is recurrent but not periodic; in duration business cycles vary from more than one year to ten or twelve years; they are not divisible into shorter cycles of similar character with amplitudes approximating their own".

${ }^{2}$ A number of studies focus on the estimation of the level of business cycle synchronisation in EU and elsewhere. Among the plethora of studies, the interested reader is referred to Dufrénot and Keddad (2014), Degiannakis et al. (2014), Papageorgiou et al. (2010), Chen and Mills (2009), de Haan et al. (2008).
} 
tool for macroeconomic stabilisation. However, when a country is impacted by an asymmetric shock (thus, its cycle becomes de-synchronised with the union-wide business cycle), or impacted asymmetrically by a common economic shock (once again this will lead to a desynchronisation of its business cycle with the union-wide cycle), independent fiscal policy can be used as a macroeconomic stabilisation tool. As such national fiscal policies in the Eurozone take on an additional role in promoting the cyclical synchronisation of Eurozone economies with the aggregate Euro-wide business cycle.

Hence, understanding the effects of fiscal policy and the role it has played in determining business cycle synchronisation in the Eurozone is a pertinent and timely research question. As the architecture of EMU continues to evolve following the Global Financial Crisis of 2007-09 and the subsequent Eurozone debt crisis, it is of major importance to understand how fiscal policy impacts business cycle synchronisation. Thus, this paper examines the effects of fiscal policy on business cycle synchronisation between the $10^{3}$ of the initial EMU12 member-countries and the EMU12-wide business cycle, using a time-varying framework.

Our evidence suggests that fiscal policy exercises a significant effect on business cycle synchronisation across all 10 EMU member-countries, although not to the same magnitude. In addition, this effect is both time-varying and country specific. Interestingly, we cannot claim that fiscal policy effects on business cycle synchronisation are different either in the pre or the post EMU period or between the core and peripheral EMU countries. Prominent among our results is that despite the fact that fiscal policy could increase business cycle synchronisation; there is no evidence that it has consistently been used in such a way.

The paper is structured as follows. Section 2 reviews the related literature, Section 3 describes the research question to be investigated, whereas, Sections 4 and 5 present the data and the Diag-BEKK model framework, respectively. Section 6 outlines the descriptive findings of the research and Section 7 analyses the time-varying effects of fiscal policy on business cycle synchronisation. Finally, Section 8 concludes the study along with a discussion of the policy implications.

\section{Fiscal policy and business cycles}

As aforementioned, the degree of business cycle synchronisation has an impact on the effectiveness of policies set by the central bank of a monetary union. In the case of synchronous cycles among the different economies that compose a monetary union, the central bank can

\footnotetext{
${ }^{3}$ The choice of 10 EMU countries was due to reasons of data availability as explained in the data section.
} 
impose stabilisation policies with greater ease (see, for example, Clarida et al., 1999; Rogoff, 1985). In the event that individual economies face asymmetric shocks, or react asymmetrically to symmetric shocks, fiscal authorities ought to use their fiscal policy to counterbalance the negative impacts of the common monetary policy (Crowley and Schultz, 2010). As Lane (2006, p.61) suggests for the EMU, 'with a common monetary policy, national fiscal policies become the major tool by which governments can dampen fluctuations in output'. Fatas and Mihov (2009) also emphasise the fact that EMU member-countries should use their fiscal policy more actively in the monetary union in order to smooth their business cycles, since individual monetary policies are absent.

Applying fiscal policy to dampen fluctuations in output in a monetary union will involve reacting to asymmetric shocks, as well as, reacting to symmetric shocks with asymmetric impacts. The ability of any country's economy to react to either shock, without fiscal policy intervention, will differ due to heterogeneous structural factors across countries, such as the degree of wage and price flexibility and the degree of labour mobility across countries. Such structural differences promote the need for and use of fiscal policy (Van Aarle and Garretsen, 2000). Along a similar vein, Bearce (2009) suggests that fiscal policy divergence within EMU may be necessary when macroeconomic convergence has not been achieved. Hence, the expanded role for fiscal policy, as a result of EMU membership, will differ across countries depending on the individual economic structures of the national economy.

An additional implication for the impact of fiscal policy on business cycle synchronisation is related to the objectives for which national fiscal policies are used. A political economy approach to fiscal policy emphasises that policy makers may not always use fiscal policy in a countercyclical fashion. Thus, the outcome of fiscal policy may be a deficit bias (Alesina and Tabellini, 1990; Persson and Svensson, 1989), a procyclical fiscal policy (Lane 2003) or even a business cycle driven by fiscal policy shocks (Fatas and Mihov, 2007; Drazen, 2000). Due to such potential outcomes, the institutions of EMU have constrained the use of fiscal policy through the Maastricht Treaty, The Stability and Growth Pact and more recently through the Fiscal Compact Treaty.

Fatas and Mihov (2009) provide a useful review of the literature on the actual behaviour of fiscal policy in the EMU, reporting that fiscal policy is mildly procyclical. Furthermore, Gali and Perotti (2003) provide evidence that the fiscal constraints imposed in the Eurozone have been supportive of countercyclical fiscal policy. Fiscal policy is shown to change from being procyclical to countercyclical in the post Maastricht period. They opine that the Maastricht 
Treaty encouraged discretionary fiscal policies to become more countercyclical over time in the Eurozone. This occurs because fiscal policy is constrained, thus, reducing policy induced fluctuations, allowing automatic stabilisers to take a more important role. However, Fatas and Mihov (2009) have not found any change in fiscal policy as a result of the Maastricht constraints or the adoption of the single currency, i.e. it remains mildly procyclical.

However, Candelon et al. (2010) claim that there is an increase in the procyclical behaviour of fiscal policy during the post Maastricht period. They interpret this as evidence of the constraints tying the hands of fiscal policy makers. Thus, Bearce (2009) argues that greater flexibility is required under the Stability and Growth Pact in order for the EMU membercountries to achieve greater macroeconomic synchronisation. Furceri (2009) and Fatas and Mihov (2003, 2006), on the other hand, suggest that unconstrained idiosyncratic fiscal policy is often a source of macroeconomic destabilisation and increased business cycle volatility, which in turn leads to the reduced synchronisation between business cycles. Thus, fiscal policy constraints could be useful in avoiding such destabilisation.

No matter whether fiscal policy is applied in a countercyclical, procyclical or acyclical manner, its impact on business cycle synchronisation is an empirical question investigated by this study. The estimation of a time varying measure of business cycle synchronisation and the impact of fiscal policy on that level of synchronisation will provide evidence (i) on how fiscal policy impacts synchronisation and (ii) whether or not there has been a discernible change in the impact of fiscal policy overtime on this synchronisation.

There are two main channels via which fiscal policy can impact business cycle synchronisation. Fiscal policy will impact on a country's business cycle synchronisation with the aggregate EMU12-wide cycle directly through its impact on the domestic economy or indirectly through spillover effects.

The impact of fiscal policy on the domestic economy has been a divisive issue among economists for some time, and the controversy has increased since the Global Financial Crisis of 2007-09. Initially following the onset of the crisis there was widespread resort to fiscal stimulus, suggesting acceptance of a Keynesian approach to the negative demand shock (see, Krugman, 2012, for example). Critics of this approach argued that the fiscal stimulus was misguided and as debts and deficits grew it was more appropriate to restore balance to the public finances. Some claimed that restoring fiscal stability would engender an improvement in confidence, thus stimulating increased consumption, investment and growth. The theoretical and empirical support for these confidence effects of fiscal policy was provided in the seminal 
work of Giavazzi and Pagano (1990) ${ }^{4}$. This research has influenced the "austerity" approach; whereby, under certain circumstances, a fiscal contraction may have an expansionary effect on the economy. However, recently Alesina and Ardagna (2010, p.35) have remarked that we still know “... relatively little about the effect of fiscal policy...".

In attempting to reconcile these conflicting approaches, and to better understand the impacts of fiscal policy, an extensive body of recent research has focused on the size of fiscal multipliers. Cogan et al. (2010) has question whether fiscal stimulus can be effective due to a small fiscal multiplier. Ilzetzki et al. (2013) find a negative multiplier in high debt countries, while other research distinguishes the size of fiscal multipliers during recessions and expansions, and reports fiscal multipliers to be much greater during recessions (Auerbach and Gorodnichenko, 2012; Corsetti et al., 2012). Furthermore, using sub-national data Acconcia et al. (2014) have found multipliers as high as 1.9. These large fiscal multipliers suggest that fiscal policy could play an important role in determining business cycle synchronisation in EMU.

In addition, an individual EMU country's fiscal policy may also have spillover effects on other member countries and, thus, can affect business cycle synchronisation (Corsetti et al., $2010)^{5}$. We maintain that EMU countries are interconnected not only through their currency but also through trade linkages. Thus, fiscal policy decisions in any one country are likely to have spillover effects into other countries, which are transmitted directly or indirectly via trade linkages. As such, a fiscal stimulus in one member-country could result in public spending falling directly on trading partners' exports. Additionally, fiscal stimulus which expands economic activity in the home country may indirectly increase trading partners' exports. In any case, exports of a member-country could increase due to a fiscal stimulus in another membercountry. The reverse of course holds true in the case of a fiscal contraction. Beetsma et al. (2006) and Giuliodori and Beetsma (2004) provide evidence of the importance of fiscal policy spillovers in Europe.

\footnotetext{
${ }^{4}$ Subsequent to Giavazzi and Pagano(1990) research focused on the theoretical considerations under which a fiscal contraction could be expansionary, these papers included, for example, Blanchard (1990), Drazen (1990), Bertola and Drazen (1993), Barry and Devereux (1995), Sutherland (1997), Perotti (1999) and Barry and Devereux (2003). Accompanying these theoretical papers several empirical papers tested whether a fiscal contraction could be expansionary in a variety of cross-country empirical studies, including inter alia Alesina and Perotti (1995), Giavazzi and Pagano (1996), McDermott and Westcott (1996), Alesina et al.(1998), Perotti (1999), Alesina et al.(2002), Perotti (2004), Perotti (2007), Alesina and Aardagna (2010), Romer and Romer (2010), IMF (2010) and Perotti (2011).

${ }^{5}$ Cassette et al. (2013) also suggests that fiscal decisions are influenced by the interconnectedness among neighbouring countries, either due to geographic proximity or economic leadership.
} 
Furthermore, any spillover effects from a large country's fiscal policy would be expected to be greater due to the impact scale. For example, given that Germany's GDP is almost $30 \%$ of EMU GDP, we could expect to observe greater potential spillover effects. Thus, it could be expected that the fiscal policies of larger countries could have sizeable effects on smaller countries' business cycles. Considering though that this is the first study to examine the time-varying effects of fiscal policy on business cycle synchronisation, we do not separate these possible spillover effects of fiscal policy but rather we leave it for further study. In this study we solely focus on the overall effect of fiscal policy on business cycle synchronisation.

Overall, the focus on the effects of fiscal policy on business cycle synchronisation is still rather limited in the literature ${ }^{6}$. Studies such as Crespo-Cuaresma et al. (2011), Inklaaret al. (2008), as well as, Böwer and Guillemineau (2006) and Darvas et al. (2005) indicate that greater fiscal policy convergence contributes to increased business cycle synchronisation. Nevertheless, none of the aforementioned studies have investigated the time-varying effects of fiscal policy on business cycle synchronisation, but rather, they use a static framework.

Thus, the present study adds to the literature on the impact of fiscal policy on business cycle synchronisation in a time-varying environment. We do not consider fiscal policy convergence among the EMU member-countries, but rather we examine the effect of individual countries' fiscal policy on the level of business cycle synchronisation between that country's and the aggregate EMU12-wide business cycle. As such this approach directly examines how and if an individual country's fiscal policy promotes business cycle synchronisation. Furthermore, previous studies do not allow for a time-varying impact of fiscal policy on business cycle synchronisation. This study is the first to utilise a time-varying framework to examine the effects of fiscal policy on business cycle synchronisation. The effects are examined in this framework to allow for variation over time associated with changing EU institutions and variations in national domestic fiscal priorities.

This paper provides evidence of the impact of fiscal policy on business cycle synchronisation. The impact of fiscal policy on business cycle synchronisation is countryspecific and is not constant across time. Moreover, none of the countries examined consistently use fiscal policy to promote business cycle synchronisation.

\footnotetext{
${ }^{6}$ The existing literature mainly concentrates its attention on other determinants of business cycle synchronisation, such as, trade intensity, financial integration, industrial specialisation, similarity in industrial structure, factor endowments, distance between countries, language, adjacency, political ideology and global economic shocks (see, Cerqueira and Martins, 2011; Kose et al., 2008; de Haan et al., 2008; Calderon et al., 2007; Kose and Yi, 2006; Imbs, 2004, 2006; Morgan et al., 2004; Kose et al., 2003a, 2003b; Frankel and Rose, 1998; Canova and Dellas, 1993).
} 


\section{Dynamic Correlation between Business Cycles and Fiscal Policy}

An optimum currency area is enhanced when policy promotes synchronisation between national business cycles and the aggregate monetary union-wide cycle. If we denote the business cycle of country $i$, at time $t$, as $c_{i, t}$, and the union wide cycle as $c_{M U, t}$, then the relationship between the two cycles is expressed as:

$$
c_{M U, t}=\phi_{i, t} c_{i, t},
$$

and each country's target is $\phi_{i, t} \rightarrow 1$, where $\phi_{i, t}$ denotes the level of synchronisation.

We claim that each country's business cycle fluctuations are related to certain economic variables, $\boldsymbol{\Omega}_{i, t-k}$, as well as, to the fiscal policy, $x_{i, t-k}$, such that:

$$
c_{i, t}=f\left(\boldsymbol{\Omega}_{i, t-k}\right)^{7} .
$$

The $\boldsymbol{\Omega}_{i, t-k}$ and $x_{i, t-k}$ are defined at time $t-k$ for $k=0,1, \ldots, n$, to focus on the reaction of the business cycle to economic condition ${ }^{8}$. The business cycle's fluctuations which are not related to fiscal policy are denoted as:

$$
c_{i, t}^{*}=c_{i, t}-g\left(x_{i, t-k} ; k=0,1, \ldots, n\right),
$$

where $g($.) denotes a function (linear or non-linear) of fiscal policy at time $t-k$. Hence, the level of business cycle synchronisation between country $i$ and the monetary union, having disentangled country's $i$ fiscal policy effect, can be defined as:

$$
c_{M U, t}=\phi_{i, t}^{*} c_{i, t}^{*} \text {. }
$$

The quantity

$$
\phi_{i, t}-\phi_{i, t}^{*}
$$

\footnotetext{
${ }^{7} f\left(\right.$.)represents a function - linear or non-linear - of $\boldsymbol{\Omega}_{i, t-k}$, where $x_{i, t-k} \subset \boldsymbol{\Omega}_{i, t-k}$.

${ }^{8}$ As we focus on the reaction of business cycle to fiscal policy changes and not on the effects of the business cycle on the deficit, a lagged relationship of $c_{i, t}=f\left(x_{i, t-k}\right)$ could be considered; i.e. previous year's fiscal policy changes could matter to current year's synchronisation. However, this approach would underestimate the impact of the fiscal policy in very flexible economies where the economic reactions to fiscal shocks are short lived; $c_{i, t}=f\left(x_{i, t}\right)$ . According to Mertens and Ravn (2012) and Blanchard and Perotti (2002) for the US case, and Giuliodori and Beetsma (2009) for Europe, fiscal policy has non-negligible effects in the very short term, and they can die out very fast. Additionally, the political environment in any specific member state likely will determine the distribution of the fiscal stimulus impact to aggregate demand over a longer than one year horizon. More open governments will tend to front load most of the impact to the first year, or even before that if households have rational expectations, whereas governments that tend to have surprising changes in fiscal policy, perhaps because of a more opaque political process or because of changing coalition partner demands, will likely have a greater weight on the second year impact. In order to incorporate such aspects in the analysis, we assume a multiple-years relationship between fiscal policy and business cycles, i.e. $c_{i, t}=f\left(x_{i, t-k}\right)$, for $k=0,1,2 \ldots, n$.
} 
explains the impact of fiscal policy on the synchronisation level between the union-wide and country $i$ 's business cycles. The research question this paper examines is whether:

Country $i$ 's fiscal policy does affect the level of business cycle synchronisation with the monetary union-wide cycle, or $\phi_{i, t}-\phi_{i, t}^{*} \neq 0$.

Arguably, the relationship between country $i$ and the union wide cycle varies across time and, thus, the effects of fiscal policy on business cycle synchronisation is also expected to be time varying. Hence, this framework captures the dynamic behaviour of fiscal authorities.

\section{Data Description}

The dataset includes annual ${ }^{9}$ GDP and Cyclically Adjusted Net Lending (NLB) ${ }^{10}$ data from $10^{11}$ EMU member-countries and the aggregate EMU12 (EMU12 core members: Austria, Belgium, Finland, France, Germany, Netherlands; EMU12 periphery members: Greece, Ireland, Italy and Portugal). The data cover the period from 1980 to $2012^{12}$. All GDP prices are expressed in logarithms; they are seasonally adjusted and refer to constant levels. The Cyclically Adjusted Net Lending data have been converted into percentages of GDP. The data are retrieved from the Annual Macro-Economic database, $\mathrm{AMECO}^{\circledR}$, of the European Commission and Datastream ${ }^{\circledR}$.

The EMU12 member-countries' GDP data are used to extract a European wide business cycle. This is the average cycle at which the common monetary policy is assumed to be responsive to. Although since its inception EMU has increased to 17 member countries we retain our focus on the original members. Cyclically adjusted net lending data is used to assess the effects of discretionary fiscal policy, in each of the sample countries, on their individual economies business cycle synchronisation with the aggregate EMU12 cycle.

The cyclical components of the log-GDP series are extracted using the Hodrick and Prescott (1997) filter, which was originally proposed by Leser (1961). Additional filtering

\footnotetext{
9 The use of annual data is mainly influenced by the use of fiscal variables. Fiscal data on annual basis are calculated on an accrual based approach, whereas in quarterly frequency the fiscal estimates are calculated on cash based approach (thus, not appropriately measured). Furthermore, quarterly net lending data was not available for the full sample period for all countries. In addition, the estimated output (not shown here but available upon request) provided evidence that the quarterly data are not useful for policy implication, because of the cash-based nature of variables.

${ }^{10}$ The net lending/borrowing is largely determined by the business cycle and therefore highly endogenous. Thus, the use of the cyclically adjusted net lending addresses the issue of endogeneity in our model.

${ }^{11}$ The EMU12 business cycle is estimated in the same spirit with Artis et al. (2004). Spain and Luxembourg have been omitted from the analysis due to the lack of availability of cyclically adjusted net lending for the full period. Nevertheless, we incorporated the Spanish GDP for the calculation of the EMU12 business cycle.

${ }^{12}$ For Greece the data cover the period 1988 to 2012, whereas for Ireland the data cover the period 1985 to 2012.
} 
methods have also been used (Baxter and King, 1999 filter and Christiano and Fitzgerald, 2003 band pass filter) for robustness purposes and in order to allow to the results to be comparable with the existing literature. The results are qualitatively similar.

To estimate the cyclical component, using the Hodrick and Prescott (HP) filter, we assume that the seasonally adjusted log-GDP series, $y$, is composed of a trend, $\tau$, and a cyclical component, $c$, such that:

$$
y_{t}=\tau_{t}+c_{t} .
$$

The cyclical component can be found by deducting the trend component from the actual series, assuming that irregular movements of the GDP series are zero. Thus, it is maintained that the cyclical variations represent deviations from the estimated long run trend of the series. In order to filter the trend component so that we then deduct it from the actual series, we need an appropriate smoothing parameter $\lambda$, that minimizes:

$$
\sum_{t=1}^{T} c_{t}^{2}+\lambda \sum_{t=2}^{T-1}\left[\left(\tau_{t+1}-\tau_{t}\right)-\left(\tau_{t}-\tau_{t-1}\right)\right]^{2}
$$

The first part of Eq. 7 penalizes for poor fit (i.e. large residuals), whereas the second term penalizes variability in the trend component's growth rate. The choice of the smoothing parameter $\lambda$ influences the output of the cyclical component. The larger the value of $\lambda$, the greater the penalty and, thus, the smoother the estimated trend will be. On the other hand a low value of $\lambda$ will produce a more volatile estimated trend ${ }^{13}$.

\section{Estimating the Effects of Fiscal Policy on the Dynamic Correlation}

This section describes the method used to estimate the effects of fiscal policy on business cycle synchronisation over time. Once we isolate the cyclical component of the GDP series, we adopt the following procedure, which is comprised of three steps:

Step 1: Define an estimate of the correlation between the business cycles of the 10 EU countries and the aggregate EMU12 cycle.

The research question stated in Section 2 requires the estimation of time varying $\phi_{i, t}$ and $\phi_{i, t}^{*}$ quantities. An appropriate measure of the quantities $\phi_{i, t}$ and $\phi_{i, t}^{*}$ is the correlation coefficient. If a time-invariant relationship between country $i$ and the union wide cycle had

\footnotetext{
${ }^{13}$ Hodrick and Prescott (1997) suggest that for monthly, quarterly and annual data the appropriate smoothing parameter should take the value 14400,1600 and 100 , respectively.
} 
been considered, then the level of synchronisation would have been $\phi_{i}$. In such a case, the impact of fiscal policy on the synchronisation level between the union-wide and the country $i$ business cycles would be $\phi_{i}-\phi_{i}^{*}$. The $\phi_{i}$ and $\phi_{i}^{*}$ could be estimated from $c_{M U, t}=\phi_{i} c_{i, t}+\varepsilon_{i, t}$ and

$$
c_{M U, t}=\phi_{i}^{*}\left(c_{i, t}-\beta_{i, 1} x_{i, t-k}\right)+\varepsilon_{i, t}
$$

respectively.

Considering the dynamic behaviour of business cycles and fiscal policies, such timeinvariant estimates could not provide policy information. Requiring the correlation coefficients to vary over time, we propose the estimation of $\phi_{i, t}$ and $\phi_{i, t}^{*}$ as the time-varying correlation coefficients obtained by a multivariate dynamic auto-correlated and cross-correlated framework illustrated as (introduced by Bollerslev et al., 1988):

$$
\begin{gathered}
\mathbf{c}_{t}=\mathbf{H}_{t}^{1 / 2} \mathbf{z}_{t} \\
\mathbf{z}_{t} \sim F\left(\mathbf{z}_{t} ; v, \mathbf{0}, \mathbf{I}\right) \\
\mathbf{H}_{t}=\sigma\left(\mathbf{H}_{t-1}, \mathbf{H}_{t-2}, \ldots, \boldsymbol{\varepsilon}_{t-1}, \boldsymbol{\varepsilon}_{t-2}, \ldots\right),
\end{gathered}
$$

where the vector $\mathbf{c}_{t}=\left(\begin{array}{c}c_{i, t} \\ c_{12, t}\end{array}\right)$ refers to the bivariate stochastic process under investigation; i.e. the business cycles at an annual frequency ${ }^{14}$. The $c_{i, t}$, for $i=1, \ldots, 11$, denotes the business cycles of the 10 countries, whereas the $c_{12, t}$ denotes the business cycle of the aggregate EMU12. $\mathbf{z}_{t}$ is a vector process with zero mean, $E\left(\mathbf{z}_{t}\right)=\mathbf{0}$, unit variance and zero covariance, $E\left(\mathbf{z}_{t} \mathbf{z}_{t}^{\prime}\right)=\mathbf{I}$. Its density function, $F\left(\mathbf{z}_{t} ; v, \mathbf{0}, \mathbf{I}\right)$ is defined by a vector of parameters $v$. Additionally, $\sigma($.$) is a$ positive measurable function of the lagged conditional covariance matrices and the vector of business cycles. The stationary property of the business cycle, as this has been extracted by the HP filter, justifies the estimation of the aforementioned framework.

Framework (9) presents a generalized specification of multivariate $\mathrm{ARCH}$ model ${ }^{15}$. A similar approach has been adopted by Degiannakis et al. (2014) to investigate the correlation between the EU12 business cycle and the EU12 member-countries. The $i^{\text {th }}$ diagonal element of $\mathbf{H}_{t}$ expresses the dynamic variance of $c_{i, t}$, or $\sigma_{i, t}^{2}$, whereas, the $i, j^{\text {th }}$ non-diagonal element of

\footnotetext{
${ }^{14}$ The business cycles are stationary according to the ADF, PP and KPSS unit root tests. The results are available upon request.

${ }^{15}$ Technical details for the multivariate time-varying correlation models are available in Xekalaki and Degiannakis (2010, p.446).
} 
$\mathbf{H}_{t}$ expresses the dynamic covariance between $c_{i, t}$ and $c_{j, t}$, or $\sigma_{i, j, t}$. Hence, the time varying approximation of $\phi_{i, t}$ is, then, estimated as:

$$
\hat{\phi}_{i, t} \equiv \rho_{i, 12, t}=\frac{\sigma_{i, 12, t}}{\sqrt{\sigma_{i, t}^{2} \sigma_{12, t}^{2}}} .
$$

In order to estimate framework (9), we utilize the Diag-BEKK ${ }^{16}$ structure for the variance-covariance matrix $\mathbf{H}_{t}$, introduced by Engle and Kroner (1995), and the standard normal density function for the vector process $\mathbf{z}_{t}$. The appropriateness of the Diag-BEKK specification for modelling the conditional covariance matrix has been tested for residuals' serial correlation with Lütkepohl's (2007) multivariate Q-statistic and for the presence of ARCH effects in the residuals with Tse's (2002) test. The conditional covariance matrix has been investigated in the general form: $\mathbf{H}_{t}=\mathbf{A}_{\mathbf{0}}+\sum_{i=1}^{q} \widetilde{\mathbf{A}}_{i} \boldsymbol{\varepsilon}_{t-i} \boldsymbol{\varepsilon}_{t-i}^{\prime} \widetilde{\mathbf{A}}_{i}^{\prime}+\sum_{i=1}^{p} \widetilde{\mathbf{B}}_{i} \mathbf{H}_{t-i} \widetilde{\mathbf{B}}_{i}^{\prime}$, The lag orders $p, q$ have been investigated according to Schwarz's (1978) Bayesian information criterion. An asymmetric form of the Diag-BEKK model has been estimated but the asymmetric coefficients are statistically insignificant. Thus, the standard likelihood ratio test and the model selection information criteria proposed the symmetric form of the Diag-BEKK model. The Diag-BEKK with standard normal distribution is defined as:

$$
\begin{gathered}
\mathbf{c}_{t}-\left(\begin{array}{c}
\beta_{i, 0} \\
\beta_{12,0}
\end{array}\right)=\mathbf{H}_{t}^{1 / 2} \mathbf{z}_{t} \\
\mathbf{z}_{t} \sim N\left(\mathbf{z}_{t} ; \mathbf{0}, \mathbf{I}\right) \\
\mathbf{H}_{t}=\mathbf{A}_{\mathbf{0}}+\widetilde{\mathbf{A}}_{1} \boldsymbol{\varepsilon}_{t-1} \boldsymbol{\varepsilon}_{t-1}^{\prime} \widetilde{\mathbf{A}}_{1}^{\prime}+\widetilde{\mathbf{B}}_{1} \mathbf{H}_{t-1} \widetilde{\mathbf{B}}_{1}^{\prime},
\end{gathered}
$$

where $\boldsymbol{\varepsilon}_{t} \equiv \mathbf{c}_{t}-\left(\begin{array}{ll}\beta_{i, 0} & \beta_{12,0}\end{array}\right)^{\prime}$ is the de-meaned $\mathbf{c}_{t}$, with a conditional covariance matrix denoted as $\mathbf{H}_{t}$. The Diag-BEKK specification defines a positive definite $\mathbf{H}_{t}$ matrix. The $\mathbf{z}_{t} \sim N\left(\mathbf{z}_{t} ; \mathbf{0}, \mathbf{I}\right)$ is the bivariate standard normal density function. The $\beta_{i, 0}$ and $\beta_{12,0}$ coefficients

\footnotetext{
${ }^{16}$ The aim of this paper is to inform policy decision makers on the effects of fiscal policy on business cycle synchronisation. The use of annual data, which are flatter compared to those sampled on quarterly frequency, demand for models that can capture the full dynamics of the volatility and covariance estimates, such as the BEKK model. In order to estimate bivariate covariance matrices, the Diag-BEKK specification is preferable compared to models whose success depends on their ability to estimate large time varying covariance matrices such as Engle's (2002) Dynamic Conditional Correlation model. Moreover, it involves the estimation of less number of parameters than other multivariate GARCH models like Engle's et al. (1986) VECH model, Baba's et al. (1990) BEKK model, etc. If quarterly data could have been used then these data would require models that provide smoother volatility and covariance estimates, such as the RiskMetrics which is more parsimonious (see Degiannakis et al., 2014).
} 
denote the average value of the business cycle of the $i^{\text {th }}$ country and the business cycle of the aggregate EMU12, respectively.

The covariance matrix of the Diag-BEKK model is defined as:

$$
\begin{array}{r}
\mathbf{H}_{t}=\left(\begin{array}{cc}
\sigma_{i, t}^{2} & \sigma_{i, 12, t} \\
\sigma_{i, 12, t} & \sigma_{12, t}^{2}
\end{array}\right)=\left(\begin{array}{ll}
a_{1,1} & a_{1,2} \\
a_{1,2} & a_{2,2}
\end{array}\right)+\left(\begin{array}{cc}
\widetilde{a}_{1,1} & 0 \\
0 & \widetilde{a}_{2,2}
\end{array}\right)\left(\begin{array}{cc}
\varepsilon_{i, t-1}^{2} & \varepsilon_{i, t-1} \varepsilon_{12, t-1} \\
\varepsilon_{i, t-1} \varepsilon_{12, t-1} & \varepsilon_{12, t-1}^{2}
\end{array}\right)\left(\begin{array}{cc}
\widetilde{a}_{1,1} & 0 \\
0 & \widetilde{a}_{2,2}
\end{array}\right)^{\prime} \\
+\left(\begin{array}{cc}
\widetilde{b}_{1,1} & 0 \\
0 & \widetilde{b}_{2,2}
\end{array}\right)\left(\begin{array}{cc}
\sigma_{i, t-1}^{2} & \sigma_{i, 12, t-1} \\
\sigma_{i, 12, t-1} & \sigma_{12, t-1}^{2}
\end{array}\right)\left(\begin{array}{cc}
\widetilde{b}_{1,1} & 0 \\
0 & \widetilde{b}_{2,2}
\end{array}\right)^{\prime}
\end{array}
$$

The time-varying correlation of the $i^{\text {th }}$ country's business cycle and the aggregate EMU12 business cycle, $\rho_{i, 12, t}$, which corresponds to the synchronisation quantity $\phi_{i, t}$, is estimated as:

$$
\rho_{i, 12, t}=\frac{\sigma_{i, 12, t}}{\sqrt{\sigma_{i, t}^{2} \sigma_{12, t}^{2}}}=\frac{a_{1,2}+\tilde{a}_{1,1} \varepsilon_{i, t-1} \varepsilon_{12, t-1} \tilde{a}_{2,2}+\tilde{b}_{1,1} \sigma_{i, 12, t-1} \tilde{b}_{2,2}}{\left.\sqrt{\left(a_{1,1}+\widetilde{a}_{1,1}^{2} \varepsilon_{i, t-1}^{2}+\tilde{b}_{1,1}^{2} \sigma_{i, t-1}^{2}\right)\left(a_{2,2}+\widetilde{a}_{2,2}^{2} \varepsilon_{12, t-1}^{2}+\widetilde{b}_{2,2}^{2} \sigma_{12, t-1}^{2}\right.}\right)}
$$

The proposed structure of $\mathbf{A}_{0}, \widetilde{\mathbf{A}}_{1}$ and $\widetilde{\mathbf{B}}_{1}$, produces time-varying covariances (numerator of equation above). Otherwise (in case of constant covariance), a time-varying correlation due to the time-varying standard deviations would lead to an increase/decrease in synchronisation in less/more volatile periods.

Step 2: Define an estimate of the correlation between the business cycles of the 10 EU countries and the aggregate EMU12 cycle, which is not explained by the fiscal deficit.

The Diag-BEKK model specification is reformed in order to capture the effect of the current and/or previous years' fiscal deficit to the current year's business cycle. Let the variable $x_{i, t}$ refer to the fiscal deficit of the $i^{t h}$ country. Then, the term $\varepsilon_{i, t}=c_{i, t}-\beta_{i, 0}-\beta_{i, 1} x_{i, t-k}$ expresses the business cycle of the $i^{\text {th }}$ country, at year $t$, that is not explained by the current and/or previous years' fiscal deficit. The lags $k=0,1, \ldots, n$ incorporated into the model are selected according to the Schwarz (1978) Bayesian criterion. We model the contemporaneous, $k=0$, and the lagged effects, $k \geq 1$, of fiscal policy to business cycle as i) the fiscal policy has non-negligible effects in the very short term, ii) open governments tend to front load most of the impact of fiscal changes to the first year, iii) governments that tend to have surprising changes in fiscal policy have a greater weight on the second year impact. 
The intention is to capture the time-varying correlation between the business cycles of $10 \mathrm{EU}$ countries and the aggregate EMU12 business cycle which does not emanate from the fiscal deficit. The Diag-BEKK model framework is reformed as:

$$
\begin{array}{r}
\left(\begin{array}{c}
c_{i, t} \\
c_{12, t}
\end{array}\right)=\left(\begin{array}{c}
\beta_{i, 0}+\beta_{i, 1} x_{i, t-k} \\
\beta_{12,0}
\end{array}\right)+\boldsymbol{\varepsilon}_{t} \\
\boldsymbol{\varepsilon}_{t}=\mathbf{H}_{t}^{1 / 2} \mathbf{z}_{t} \\
\mathbf{z}_{t} \sim N\left(\mathbf{z}_{t} ; \mathbf{0}, \mathbf{I}\right) \\
\mathbf{H}_{t}=\mathbf{A}_{\mathbf{0}}+\widetilde{\mathbf{A}}_{1} \boldsymbol{\varepsilon}_{t-1} \boldsymbol{\varepsilon}_{t-1}^{\prime} \widetilde{\mathbf{A}}_{1}^{\prime}+\widetilde{\mathbf{B}}_{1} \mathbf{H}_{t-1} \widetilde{\mathbf{B}}_{1}^{\prime},
\end{array}
$$

The time-varying correlation of the $i^{\text {th }}$ country's business cycle and the aggregate EMU12 cycle which is not explained by the previous year's fiscal deficit, $\rho_{i, 12, t}^{*}$, which corresponds to the synchronisation quantity $\phi_{i, t}^{*}$, is estimated as

$$
\rho_{i, 12, t}^{*}=\frac{\sigma_{i, 12, t}}{\sqrt{\sigma_{i, t}^{2} \sigma_{12, t}^{2}}}
$$

from framework (14).

Step 3: Estimate the impact of fiscal policy on the synchronisation of the business cycles.

The difference between the time-varying correlations $\rho_{i, 12, t}$ and $\rho_{i, 12, t}^{*}$ explains the impact of lagged fiscal policy on the synchronisation of the $i^{\text {th }}$ country's business cycle with the aggregate EMU12 business cycle. A positive difference indicates that country $i$ 's lagged fiscal policy promotes greater synchronisation with the aggregate EMU12 business cycle, whereas the reverse applies for a negative difference. A zero difference implies that fiscal policy has not impacted on business cycle synchronisation.

\section{Some business cycles and fiscal policy descriptive statistics}

Figure 1 presents the cyclical component of the business cycle for each EMU membercountry as well as for the EMU12 and Table 1 exhibits their descriptive statistics. The business cycle is presented as a percentage of each country's GDP to enable comparisons across different sized economies.

[FIGURE 1 HERE]

\section{[TABLE 1 HERE]}

The business cycles are presented in terms of country groups for ease of exposition. All business cycles follow a similar pattern, nevertheless the EMU periphery countries seem to 
exhibit a more amplified variation. This is also evident by the standard deviation of these countries' business cycles, as shown in Table 1. That is indicative of a core-periphery divide in business cycles, as established by Agresti and Mojon (2001), and Wynne and Koo (2000). Although, Italy is not considered a core country, its business cycle is similar to those of the core EMU countries. Similarly, Finland's business cycle also exhibits higher amplitude, which resembles the behaviour of the periphery's business cycles. From Table 1 we also observe that cycles have a mean of almost zero, as expected.

Concerning the fiscal deficit, the descriptive statistics shown in Table 2 demonstrate that Greece, Portugal, Italy, and Belgium experience significantly higher deficits compared to the average EMU12 and those of the core EMU countries, such as Austria, Germany and Netherlands. It is interesting to note that Finland has on average a fiscal surplus. Furthermore, the high standard deviations of Belgium, Greece, Ireland and Italy imply a more active fiscal policy in these countries.

In addition, Figure 2 informs us that fiscal policy has not been very responsive to business cycle fluctuations (as a countercyclical fiscal policy might suggest it ought to be), as the constantly negative values imply a fiscal deficit bias. The pattern of fiscal deficit is also observed in the core EMU countries. Overall, during the period under examination, fiscal policy has been in deficit as shown in the aggregate EMU12 data, which is in line with the well-known deficit bias in fiscal policy of Tabellini and Alesina (1990) and Persson and Svensson (1989).

\section{[FIGURE 2 HERE]}

\section{[TABLE 2 HERE]}

The observed deficit is gradually reduced during the run-up to EMU which is indicative of the adjustments these countries made to fiscal policy prior to EMU membership.

Turning our attention to the time-varying synchronisation, we can observe the following empirical regularities (see Figure 3). First, the synchronisation level is fairly high, on average, during most of the period of this study for all member countries. Second, Ireland and Germany are the only two countries that exhibit any negative correlation with the EMUwide cycle. Third, since the inception of the common currency, we observe that there is an increase in the synchronisation level, although this is more apparent for the core EMU countries. Forth, since the onset of the European Debt crisis in 2010 we observe a divergence in the level of synchronisation among the member-countries and the EMU-wide cycle. More importantly, de-synchronisation is observed between the German business cycle and that of the EMU-wide cycle. 
[FIGURE 3 HERE]

Having examined the countries' business cycles, fiscal policy stances and their synchronisation level with the aggregate EMU-wide cycle, we further analyse the impact of fiscal policy on business cycle synchronisation.

\section{The Time-varying Effects of Fiscal Policy on Business Cycle Synchronisation}

Indicatively, Tables 3 and 4 present the estimated parameters of the Diag-BEKK $(1,1)$ model for France and Italy, respectively ${ }^{17}$. Table 5 and Figure 4 present the effect of fiscal policy on business cycle synchronisation for the 10 EMU sample countries, as expressed from the difference between the estimates $\rho_{i, 12, t}$ and $\rho_{i, 12, t}^{*}$. The difference

$$
\left(\rho_{i, 12, t}-\rho_{i, 12, t}^{*}\right)
$$

quantifies the impact of fiscal policy on the synchronisation of the $i^{\text {th }}$ country's cycle with the aggregate EMU12-wide cycle. The analysis of the impact of fiscal policy on determining business cycle synchronisation reveals some interesting results.

\section{[TABLE 3 HERE]}

\section{[TABLE 4 HERE]}

From Table 5, we observe that fiscal policy over the whole sample period has on average a positive effect on the level of synchronisation in many countries, although this does not hold true for France, Germany, Netherlands and Portugal.

[TABLE 5 HERE]

This is a positive finding for the Eurozone, showing that on average fiscal policy operates to support the synchronisation of business cycles. In nearly all cases the average figure is below $10 \%$, although in four cases the impact is negative. This could be suggestive of the fact that fiscal policy may not be a very important determinant of business cycle synchronisation for most countries. However, there are two points that need to be raised. First, the standard deviations reveal that for most countries the effect of fiscal policy is not stable over the sample period but it is rather volatile. Second, the values on Table 5 do not allow for the time-varying impact of fiscal policy on business cycle synchronisation. Thus, the full picture of the effects of fiscal policy can be revealed by a time-varying approach, as illustrated in Figure 4.

\footnotetext{
${ }^{17}$ For the sake of brevity, Diag-BEKK estimates for the remaining countries are not shown here but they are available upon request. The variance covariance matrix has been estimated using the robust quasi-maximum likelihood method of Bollerslev and Wooldridge (1992).
} 


\section{[FIGURE 4 HERE]}

Contrary to the static character of the average effects of fiscal policy on business cycle synchronisation which were reported in Table 5, the panels in Figure 4 actually suggest that fiscal policy does have an economically important effect on business cycle synchronisation for nearly all countries. Even more so, for some countries, such as Finland, Germany, Greece, Italy, Ireland and Portugal, fiscal policy has a substantial effect, changing the synchronisation measure by more than $65 \%$. On the contrary, the impact in Austria and Belgium is much less sizable.

Nonetheless, the importance of fiscal policy on determining synchronisation is not the full story emerging from the results. The findings indicate that the impact of fiscal policy is country specific, as well as, time-varying. This is consistent with the findings of Candelon et al. (2010), regarding the country specific impacts of fiscal policy. With respect to the variation of the impact of fiscal policy over time, the switch in the sign of $\rho_{i, 12, t}-\rho_{i, 12, t}^{*}$ shows the change from positive to negative influences across time. There are periods that fiscal policy promotes business cycle synchronisation (the line fluctuates in the positive region), whereas at other times, fiscal policy has the opposite effect. These abrupt and irregular changes across time enhance the motivation for the estimation of the time-varying measure of the effects of fiscal policy on business cycle synchronisation.

We continue our analysis focusing on the effects of fiscal policy on business cycle synchronisation during both recessionary and non-recessionary periods. Heterogeneous behaviour is observed across the different countries and time periods. However, no discernible difference is apparent in the impact of fiscal policy on business cycle synchronisation during recessionary and non-recessionary periods. For example, during the ongoing European Debt crisis (a common shock with asymmetric responses), fiscal policy had a positive impact on synchronisation in many countries, such as Finland, Ireland or Italy. More precisely, the difference between $\rho_{i, 12, t}$ and $\rho_{i, 12, t}^{*}$ fluctuated around the $20 \%$ level, although it reached the level of $80 \%$ in the case of Finland. On the other hand, in the cases of Greece, Germany and the Netherlands, fiscal policy had a detrimental effect on business cycle synchronisation. This is especially evident in the case of Greece, where the difference between $\rho_{i, 12, t}$ and $\rho_{i, 12, t}^{*}$ was more than $40 \%$. Yet, for Austria or Belgium fiscal policy did not really have any effect on synchronisation. Similar heterogeneous observations can be also made for other European recessionary periods. 
The lack of using fiscal policy to consistently promote business cycle synchronisation may be possible due to the fact that the domestic fiscal policy stance is not explicitly targeting business cycle synchronisation. In addition, domestic fiscal policy may be influenced by politically motivated choices, which may not necessarily lead to greater synchronisation. Nevertheless, while policy makers may not be expected to use fiscal policy to promote business cycle synchronisation, the goal of macroeconomic stabilisation in a monetary union suggests that it ought to play such a role in response to asymmetric shocks.

However, the present study does not provide evidence of fiscal policy behaviour which consistently supports business cycle synchronisation. The empirical effects of fiscal policy identified here suggest that fiscal policy could play such a role. As such fiscal policy could be useful in mitigating the costs of EMU membership when structural differences or asymmetries between economies are more prevalent. Additionally, we cannot observe any discernible difference in the role of fiscal policy in determining business cycle synchronisation, either in the pre or post EMU period or between the core and peripheral EMU countries. Overall, we find evidence that none of the countries under examination consistently use fiscal policy to promote business cycle synchronisation, as macroeconomic theory suggests it ought to in a monetary union.

\section{Conclusions and Policy Implications}

A successful currency union is facilitated when its member-states have synchronised business cycles. A number of determinants of business cycle synchronisation have been identified by the literature (see, among others, Boschi and Girardi, 2011; Cerqueira and Martins, 2011; Kose et al., 2008; Imbs, 2004, 2006; Morgan et al., 2004; Kose et al., 2003a, 2003b; Frankel and Rose, 1998; Canova and Dellas, 1993), nevertheless, the existing empirical work provides scarce evidence regarding the impact of fiscal policy on business cycle synchronisation. Thus, this paper investigates the effects of individual countries' fiscal policy on the time-varying business cycle synchronisation between 10 of the initial EMU12 membercountries and the aggregate EMU12 business cycle. The study uses annual GDP and cyclically adjusted Net Lending data from 10 EMU member-countries and the aggregate EMU12. The sample period runs from 1980 to 2012 .

We maintain that understanding the potential effects of fiscal policy in determining business cycle synchronisation in the EMU is an important and timely question. This is justified by the fact that since the Global Financial Crisis of 2007-09 and the ongoing Eurozone debt 
crisis, the economic debate revolves around fiscal consolidation and its impact on economic activity, and thus on business cycles.

The evidence of the paper suggests that fiscal policy is an important determinant of business cycle synchronisation across all 10 EMU member-countries. For a number of countries, such as Finland, Germany, Greece, Italy, Ireland and Portugal, the magnitude of the fiscal policy effects is greater, whereas the impact in other countries (e.g. in Austria and Belgium) it is considerably smaller. Furthermore, we maintain that fiscal policy effects vary both across time and across countries. However, we cannot provide evidence that the importance of fiscal policy in determining business cycle synchronisation differs either in the pre or post EMU period or between the core and peripheral EMU countries.

Finally, we must emphasise that according to our findings, fiscal policy could influence business cycle synchronisation in a way that is conducive to the operation of the single currency area. However, we cannot infer that fiscal policy has consistently been used in such a way throughout the sample period. Even more, the empirical results show that the use of fiscal policy could lead to de-synchronisation of the business cycles. Nevertheless, the institutional response in the Eurozone, as exemplified most recently by the Fiscal Compact, focuses on curtailing the build-up of debt and limiting the fiscal deficit (in order to promote convergence and sustainability in public finances), despite the fact that the restrictions they impose could limit the stabilising role that fiscal policy could potentially play in EMU.

The policy implication of the aforementioned results is that fiscal stance is a useful stabilisation tool in a monetary union. The findings also suggest that the design of fiscal constraints should allow for fiscal policy to perform this role when necessary, while constraining idiosyncratic policy induced de-synchronisation. In the presence of such constraints, a union-wide borrowing facility would be useful to stabilise asymmetric shocks when domestic fiscal constraints are reached, as in the current EMU debt crisis. Alternatively, other systems of fiscal transfer across EMU would be necessary to ensure stability. The aforementioned policy implications are complementary to Colciago et al. (2008) who suggest that fiscal constraints should focus on the control of aggregate EMU debt and the pursuit of policies that are symmetrical over the cycle.

\section{References}

Acconcia, A., Corsetti, G., and Simonelli, S. (2014). Mafia and public spending: Evidence on the fiscal multiplier from a quasi-experiment. The American Economic Review, 104(7), 2185-2209. 
Agresti, A.M. and Mojon, B (2001). Some stylised facts on the euro area business cycle, ECB Working Paper series No. 95.

Alesina, A. and Barro, R.J. (2002). Currency unions, Quarterly Journal of Economics, 117, 409-36.

Alesina, A. and Ardagna, S. (2010). Large Changes in Fiscal Policy: Taxes Versus Spending, Tax Policy and the Economy, 24, 35-68.

Alesina, A., Ardagna, S., Perotti, R. and Schiantarelli, F. (2002). Fiscal Policy, Profits, and Investment. American Economic Review, 92(2), 571-89.

Alesina, A., and Perotti, R. (1995). Fiscal Expansions and Adjustments in OECD Countries, Economic Policy, 21, 207-48.

Alesina, A., Perotti, R. and Tavares, J. (1998). The Political Economy of Fiscal Adjustments, Brookings Paper on Economic Activity, 1, 197-266.

vanAarle, B. And Garretsen, H. (2000). Fiscal stabilisation in the EMU, Review of International Economics, 8, 741-759.

Artis, M., Krolzig, H.M. and Toro, J. (2004). The European business cycle, Oxford Economic Papers, 56, 1-44.

Auerbach, A. J., and Gorodnichenko, Y. (2012). Fiscal multipliers in recession and expansion. In Fiscal Policy after the Financial crisis (63-98). University of Chicago press.

Baba, Y., Engle, R.F., Kraft, D. and Kroner, K.F. (1990). Multivariate Simultaneous Generalized ARCH.Department of Economics, University of California, San Diego, Mimeo.

Barry, F. G. and Devereux, M.B. (1995). The 'Expansionary Fiscal Contraction' Hypothesis: A Neo-Keynesian Analysis. Oxford Economic Papers, 47, 249-64.

Barry, F.G. and Devereux M.B. (2003). Expansionary Fiscal Contraction: A Theoretical Exploration, Journal of Macroeconomics, 25, 1-23.

Baxter, M. and King, R.G. (1999). Measuring business cycles: Approximate band-pass filters for economic time series, The Review of Economics and Statistics, 81, 575-93.

Bearce, H.D. (2009). EMU: the last stand for the policy convergence hypothesis? Journal of European Public Policy, 16, 582-600.

Beetsma, R., Giuliodori, M. and Klaassen, F. (2006). Trade spill-overs of fiscal policy in the European Union: a panel analysis. Economic policy, 21, 639-687.

Bergman, U.M. (2006). Are European business cycles converging? Department of Economics, University of Copenhagen, Research Paper.

Bertola, G., and Drazen, A. (1993). Trigger Points and Budget Cuts: Explaining the Effects of Fiscal Austerity. American Economic Review, 83(1), 11-26.

Blanchard, O.J. (1990). Discussion in F. Giavazzi and M. Pagano 1990. Can Severe Fiscal Contractions Be Expansionary? A Tale of Two Small European Countries.NBER Macroeconomic Annual, 5, 111-16.

Blanchard, O. and Perotti, R. (2002). An Empirical Characterization of the Dynamic Effects of Changes in Government Spending and Taxes on Output, Quarterly Journal of Economics, 117(4), 1329-1368.

Bollerslev, T., Engle, R.F. and Wooldridge, J.M. (1988). A Capital Asset Pricing Model with time-varying covariances, Journal of Political Economy, 96, 116-131. 
Bollerslev, T. and Wooldridge, J.M. (1992). Quasi-maximum Likelihood Estimation and Inference in Dynamic Models with Time-Varying Covariances. Econometric Reviews, 11, 143-172.

Boschi, M. and Girardi, A. (2011). The contribution of domestic, regional and international factors to Latin America's business cycle. Economic Modelling, 28(3), 1235-1246.

Böwer, U. and Guillemineau, C. (2006). Determinants of business cycle synchronisation across Euro area countries, ECB Working paper series No. 587.

Burns, A.F. and Mitchell, W.C. (1946).Measuring Business Cycles. New York: National Bureau of Economic Research.

Calderon, C., Chong, A., and Stein, E. (2007). Trade intensity and business cycle synchronisation: Are developing countries any different?. Journal of International Economics, 71(1), 2-21.

Candelon, B., Muyskeny, J. and Vermeulen, R. (2010). Fiscal policy and monetary integration in Europe: an update, Oxford Economic Papers, 62, 323-349.

Canova, F. and Dellas, H. (1993). Trade interdependence and the international business cycle, Journal of International Economics, 34, 23-47.

Cassette, A., Creel, J., Farvaque, E. and Paty, S. (2013). Governments under influence: Country interactions in discretionary fiscal policy. Economic Modelling, 30, 79-89.

Cerqueira, P.A. and Martins, R. (2011). Is there a political dimension on business cycle synchronisation? Kyklos, 64, 329-341.

Chen, X. and Mills, T. C. (2009). Evaluating growth cycle synchronisation in the EU.Economic Modelling, 26(2), 342-351.

Christiano, L. and Fitzgerald, T.J. (2003). The bandpass filter, International Economic Review, 44, 435-65.

Clarida, R., Gali, J. and Gertler, M. (1999). The science of monetary policy: A New Keynesian perspective, Journal of Economic Literature, 37, 1661-707.

Cogan, J. F., Cwik, T., Taylor, J. B., and Wieland, V. (2010). New Keynesian versus old Keynesian government spending multipliers. Journal of Economic dynamics and control, 34(3), 281-295.

Colciago, A., Ropele, T., Muscatelli, V. A. and Tirelli, P. (2008). The Role of Fiscal Policy in a Monetary Union: are National Automatic Stabilizers Effective?. Review of International Economics, 16(3), 591-610.

Corsetti, G., Meier, A., and Müller, G. J. (2010). Cross-border spillovers from fiscal stimulus. International Journal of Central Banking, 6(1), 5-37.

Corsetti, G., Meier, A., and Müller, G.J. (2012). What determines government spending multipliers?. Economic Policy, 27(72), 521-565.

Crespo-Cuaresma, J., Pfaffermayr, M., Amador, O.F. and Keppelet, C. (2011). Macroeconomic aspects of European integration: Fiscal policy, trade integration and the European business cycle, FIW Research Report, No. 4, March.

Crowley, P.M. and Schultz, A. (2010). Measuring the intermittent synchronicity of macroeconomic growth in Europe, American Consortium on European Union Studies (ACES), Working Paper No. 2010.1. 
Darvas, Z., Rose, A. K. and Szapáry, G. (2005). Fiscal divergence and business cycle synchronisation: irresponsibility is idiosyncratic (No. w11580). National Bureau of Economic Research.

Degiannakis, S., Duffy, D. and Filis, G. (2014). Business cycle synchronisation in EU: A time-varying approach, Scottish Journal of Political Economy, 61(4), 348-370.

Drazen, A. (1990). Discussion in F. Giavazzi and M. Pagano (1990), Can Severe Fiscal Contractions Be Expansionary? A Tale of Two Small European Countries. NBER Macroeconomic Annual, 5, 117-122.

Dufrénot, G. and Keddad, B. (2014). Business cycles synchronisation in East Asia: A Markov-switching approach. Economic Modelling, 42, 186-197.

Engle, R.F. (2002). Dynamic Conditional Correlation: A Simple Class of Multivariate GARCH Models. Journal of Business and Economic Statistics, 20, 339-350.

Engle, R.F. and Kroner, K.F. (1995). Multivariate simultaneous generalized ARCH, Econometric Theory, 11, 122-150.

Engle, R.F., Granger, C.W.J., and Kraft, D. (1986). Combining Competing Forecasts of Inflation Using a Bivariate ARCH Model. Journal of Economic Dynamics and Control, 8, 151-165.

Fatas, A. and Mihov, I. (2003). The case of restricting fiscal policy discretion, Quarterly Journal of Economics, 118, 1419-1447.

Fatas, A. and Mihov, I. (2006). The macroeconomics effects of fiscal rules in the US States, Journal of Public Economics, 90, 101-117.

Fatas, A.And Mihov, I. (2009). The Euro and fiscal policy, NBER Working Paper No. 14722, National Bureau of Economic Research.

Fidrmuc, J. and Korhinen, I. (2006). Meta-analysis of the business cycle correlation between the euro area and the CEECs, Journal of Comparative Economics, 34, 518-37.

Frankel, J.A. and Rose, A.K. (1998). The endogeneity of the optimum currency area criteria, Economic Journal, 108, 1009-25.

Furceri, D. (2009). Fiscal convergence, business cycle volatility, and growth, Review of International Economics, 17, 615-630.

Gali, J. and Perotti, R. (2003). Fiscal policy and monetary integration in Europe, Economic Policy, 18, 533-72.

Giavazzi, F. and Pagano, M. (1996). Non-Keynesian Effects of Fiscal Policy Changes: International Evidence and the Swedish Experience. Swedish Economic Policy Review, 3(3), 67-103.

Giuliodori, M. and Beetsma, R. (2004). What are the spill-overs from fiscal shocks in Europe? An empirical analysis, European Central Bank, Working Paper Series, 325.

deHaan, J., Inklaar, R. and Jong-a Pin, R. (2008). Will business cycles in the euro area converge? A critical survey of empirical research, Journal of Economic Surveys, 22, 23473.

Hodrick, R. and Prescott, E. (1997). Postwar U.S. business cycles: An empirical investigation, Journal of Money, Credit and Banking,29, 1-16.

Ilzetzki, E., Mendoza, E. G., and Végh, C. A. (2013). How big (small?) are fiscal multipliers?. Journal of Monetary Economics, 60(2), 239-254. 
Imbs, J. (2004). Trade, finance, specialization and synchronisation, Review of Economics and Statistics, 86, 723-34.

Imbs, J. (2006). The real effects of financial integration, Journal of International Economics, 68, 296-324.

Inklaar, R., Jong-a Pin, R. and de Haan, J. (2008). Trade and business cycle synchronisation in OECD countries - A re-examination. European Economic Review, 52, 646-66.

International Monetary Fund (2010). World Economic Outlook: Recovery Risk and Rebalancing. October 2010.

Kose, M. A., Prasad, E. and Terrones, M. (2003a). How does globalization affect the synchronisation of business cycles? American Economic Review, 93, 57-62.

Kose, M. A., Otrok, C. and Whiteman, C. (2003b). International business cycles: world, region and country specific factors, American Economic Review, 93, 1216-39.

Kose, M. A., Otrok, C., and Whiteman, C. (2008).Understanding the evolution of world business cycles.Journal of International Economics, 75(1), 110-130.

Kose, M. A., and Yi, K. M. (2006). Can the standard international business cycle model explain the relation between trade and comovement? Journal of International Economics, 68(2), 267-295.

Lane, P. (2006). The real effects of European monetary union. Journal of Economic Perspectives, 20, 47-66.

Lane, P. (2012).The European Sovereign Debt Crisis, Journal of Economic Perspectives, 26(3), 29-68.

Leser, C. E. V. (1961). A simple method of trend construction. Journal of the Royal Statistical Society. Series B, 91-107.

Lütkepohl, H. (2007). New Introduction to Multiple Time Series Analysis. Springer Verlag, New York.

McDermott, C. J., and Westcott, R. F. (1996). An Empirical Analysis of Fiscal Adjustments.IMF Staff Papers, 43, 725-53.

Mertens, K. and Rav, M.O. (2012). Empirical Evidence on the Aggregate Effects of Anticipated and Unanticipated US Tax Policy Shocks, American Economic Journal: Economic Policy, 4(2), 145-181.

Morgan, D.P., Rime, B. and Strahan, P.E. (2004). Bank integration and state business cycles. Quarterly Journal of Economics, 119, 1555-85.

Papageorgiou, T., Michaelides, G. and Milios, J.G. (2010). Business cycles synchronisation and clustering in Europe (1960-2009). Journal of Economics and Business, 62, 419-70.

Perotti, R. (1999). Fiscal Policy in Good Times and Bad. Quarterly Journal of Economics, 114(4), 1399-436.

Perotti, R. (2004). Estimating the Effects of Fiscal Policy in OECD countries, IGIER Working Paper Series, 276.

Perotti, R. (2007). In Search of the Transmission Mechanism of Fiscal Policy, NBER Working Paper Series, 13143.

Perotti, R. (2011). The “Austerity Myth": Gain Without Pain, NBER Working Paper Series, 17571 . 
Persson, T. and Svensson, L.E.O. (1989). Why a stubborn conservative would run a deficit: Policy with time-inconsistent preferences. The Quarterly Journal of Economics, 104, 325-345.

Romer, C., and Romer, D. (2010). The Macroeconomic Effects of Tax Changes: Estimates Based on a New Measure of Fiscal Shocks, American Economic Review, 100, 763-801.

Rogoff, K. (1985). The optimal degree of commitment to intermediate monetary target, Quarterly Journal of Economics, 100, 1169-190.

Savva, C.S, Neanidis, K.C. and Osborn, D.R. (2010). Business cycle synchronisation of the Euro area with the new and negotiating member countries, International Journal of Finance and Economics, 15, 288-306.

Schwarz, G. (1978). Estimating the Dimension of a Model. Annals of Statistics, 6, 461-464.

Shambaugh, J. (2012). The Euro's Three Crisis, Brookings Papers on Economic Activity, Spring, 157-232.

Sutherland, A. (1997). Fiscal Crises and Aggregate Demand: Can High Debt Reverse the Effects of Fiscal Policy? Journal of Public Economics, 65(2), 147-62.

Tabellini, G. and Alesina, A. (1990). Voting on the budget deficit, American Economic Review, 80, 37-49.

Tse, Y.K. (2002). Residual-based Diagnostics for Conditional Heteroscedasticity Models. Econometrics Journal, 5, 358-373.

Wynne, M. and Koo, J. (2000). Business cycles under monetary union: a comparison of the EU and the US, Economica, 67, 347-74.

Xekalaki, E. and Degiannakis, S. (2010). ARCH Models for financial applications. John Wiley and Sons, New York. 
Figure 1. Business cycles $\left(c_{i, t}\right)$ of the EMU member-countries and the aggregate EMU12.
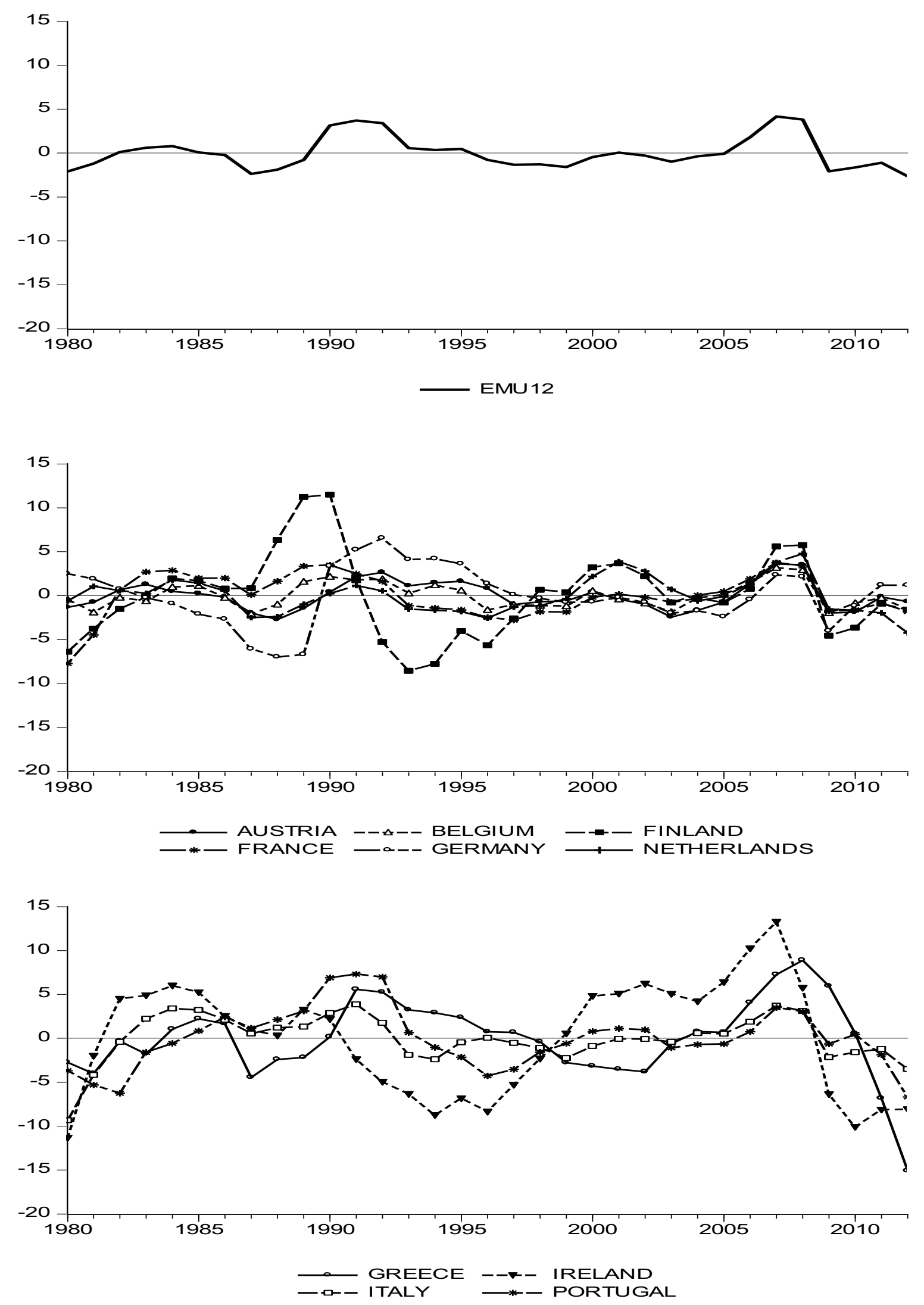
Figure 2. Cyclically Adjusted Fiscal Deficits as a percentage of GDP; $x_{i, t} / G D P_{i, t}$ of the EMU membercountries.
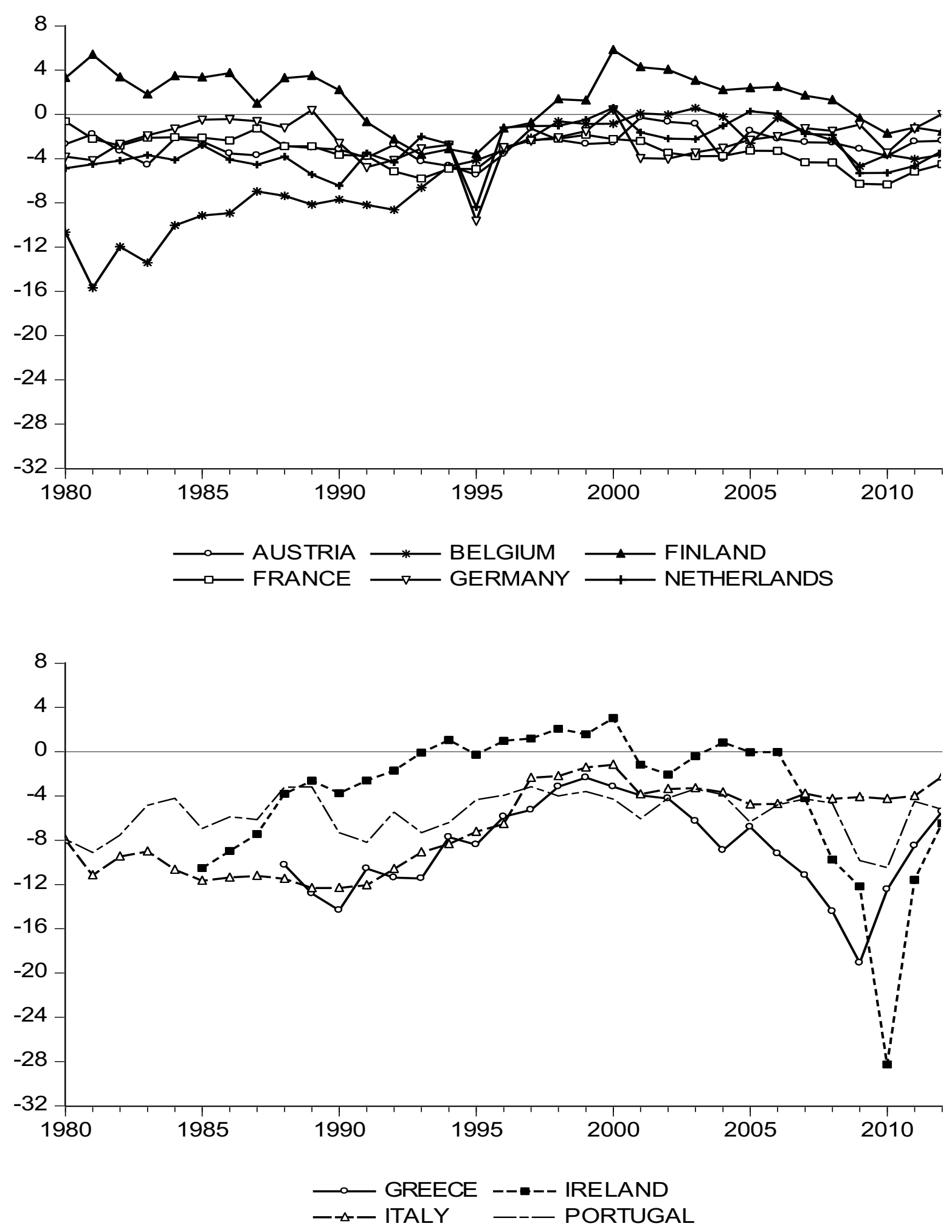
Figure 3. Time varying business cycle synchronisation between the EMU member-countries and the EMU12-wide business cycle (the line graphs plot the time-varying correlations $\rho_{i, 12, t}$ ).
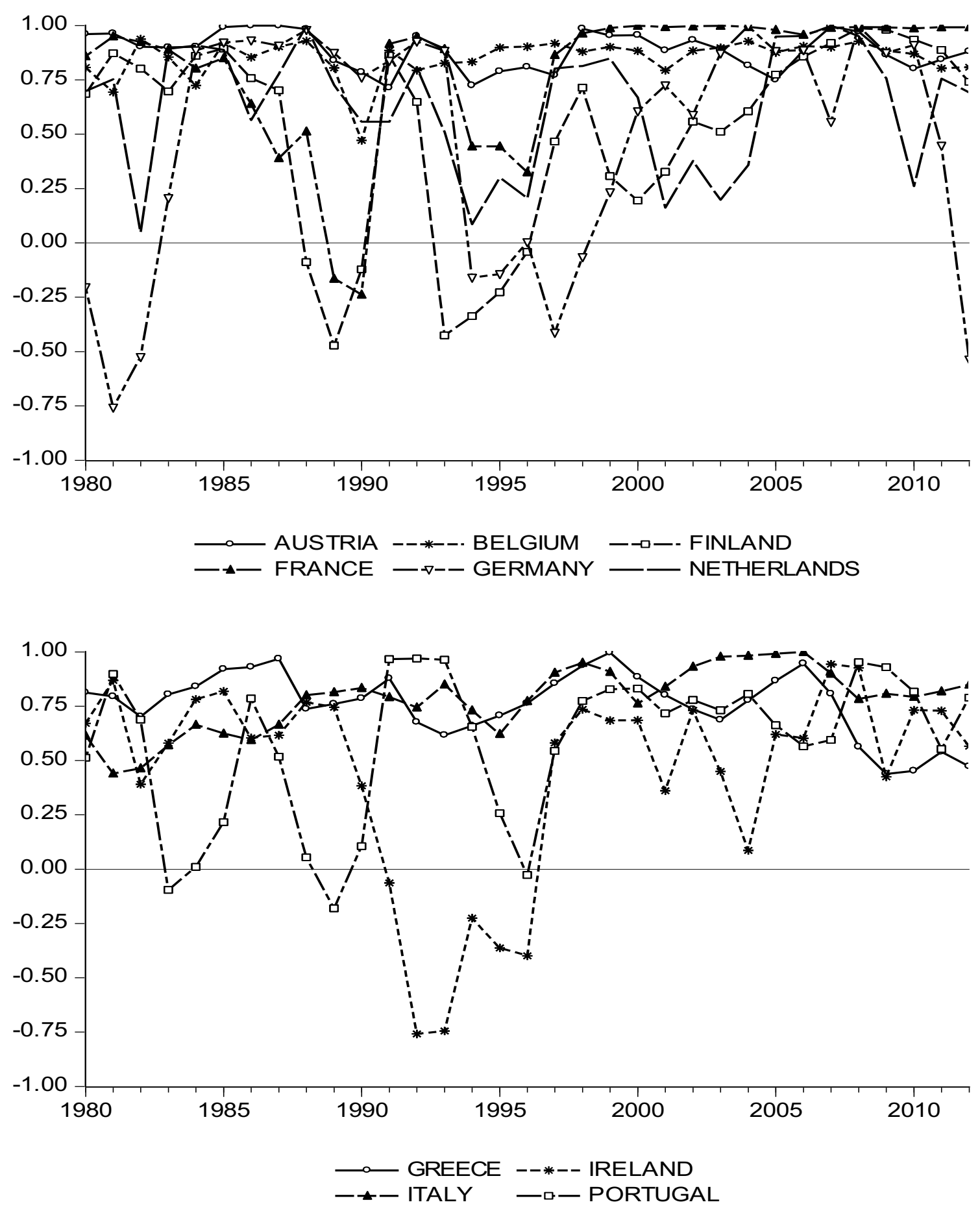
Figure 4. The impact of the cyclically adjusted fiscal deficit on the time varying business cycle synchronisation between the EMU member-countries and the EMU12-wide business cycle (the line graphs plot the percentage difference between the time-varying correlations $\rho_{i, 12, t}$ and $\rho_{i, 12, t}^{*}$ across time). The grey area surrounding the line plots the $95 \%$ confidence interval.
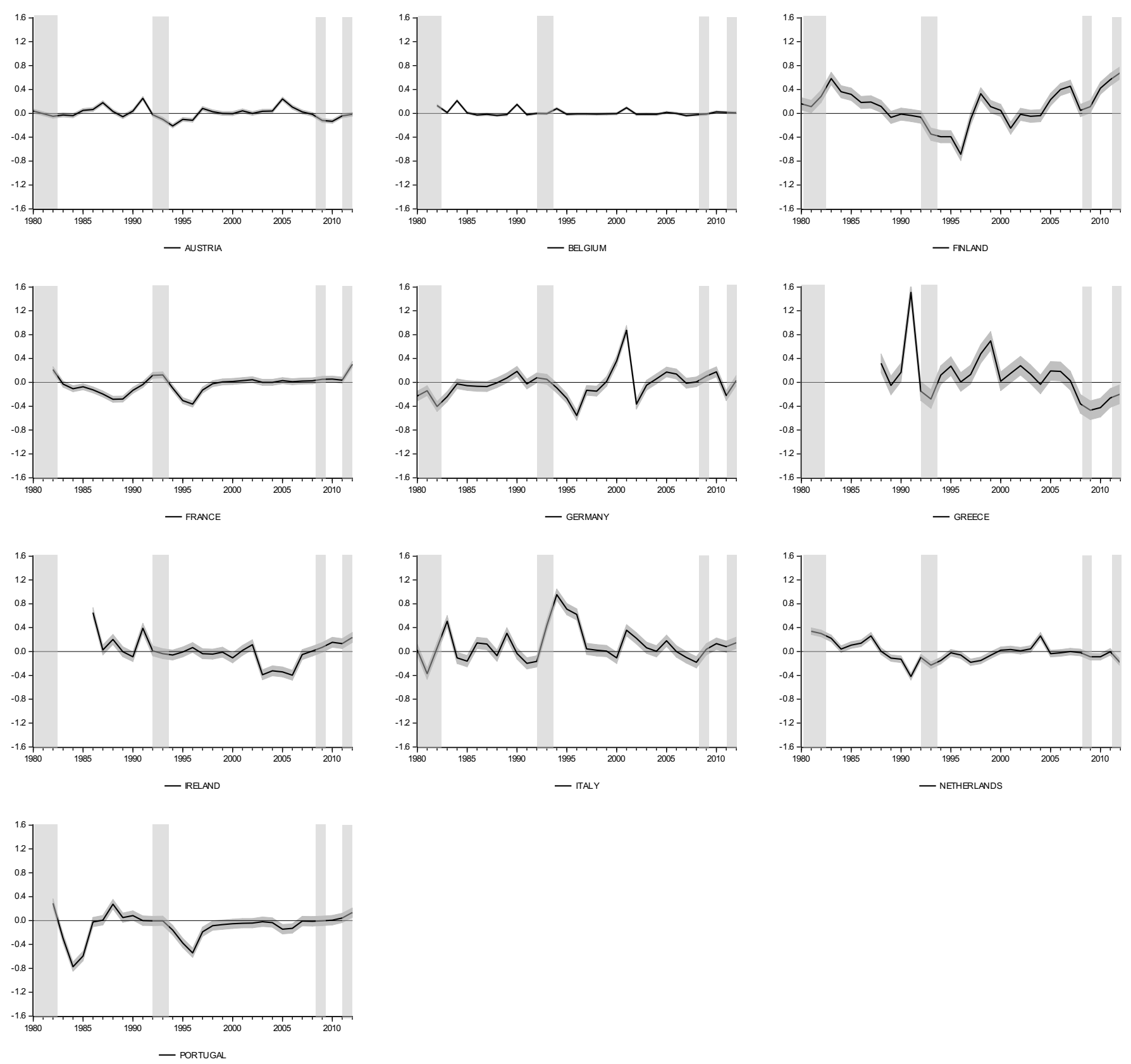

Note: The vertical grey shaded areas denote European recessions according to the CEPR Euro Area Business Cycle Dating Committee. 
Tables

Table 1. Descriptive statistics of the business cycles for the EMU member-countries and the aggregate EMU12.

\begin{tabular}{lrrrr}
\hline Country & Mean & Maximum & Minimum & Std. Dev. \\
\hline Austria & 0.0001 & 3.6048 & -2.7247 & 1.6201 \\
Belgium & 0.0002 & 3.1863 & -2.1024 & 1.4502 \\
Finland & 0.0008 & 11.4895 & -8.5633 & 4.7336 \\
France & 0.0001 & 3.7423 & -7.7335 & 2.5317 \\
Germany & 0.0003 & 6.5334 & -6.9896 & 3.2089 \\
Greece & 0.0003 & 8.8943 & -15.0973 & 4.5252 \\
Ireland & 0.0006 & 13.2649 & -11.3363 & 6.4189 \\
Italy & 0.0004 & 3.8634 & -9.3371 & 2.6915 \\
Netherlands & 0.0007 & 4.7608 & -4.2564 & 2.0534 \\
Portugal & 0.0002 & 7.3054 & -6.6771 & 3.4074 \\
EMU12 & 0.0001 & 4.1723 & -2.6531 & 1.8640 \\
\hline
\end{tabular}

Table 2. Descriptive statistics of cyclically adjusted fiscal deficits (percentage of GDP) for the EMUmember-countries.

\begin{tabular}{lrrrr}
\hline Country & Mean & Maximum & Minimum & Std. Dev. \\
\hline Austria & -2.8219 & -0.2971 & -5.4630 & 1.1613 \\
Belgium & -5.2260 & 0.5722 & -15.6908 & 4.3146 \\
Finland & 1.3316 & 5.8184 & -3.6389 & 2.5922 \\
France & -3.4010 & -0.6332 & -6.3373 & 1.4267 \\
Germany & -2.3747 & 0.4499 & -9.6104 & 1.9095 \\
Greece & -8.6851 & -2.3438 & -19.0856 & 4.1637 \\
Ireland & -3.8353 & 3.0329 & -28.2719 & 6.5072 \\
Italy & -6.8531 & -1.1804 & -12.3374 & 3.7717 \\
Netherlands & -3.0719 & 0.5956 & -8.3844 & 2.0655 \\
Portugal & -5.5969 & -3.1612 & -10.4832 & 1.9889 \\
\hline
\end{tabular}


Table 3. Estimated parameters of the Diag-BEKK $(1,1)$ model for France. The coefficient to standard error ratios are reported in brackets.

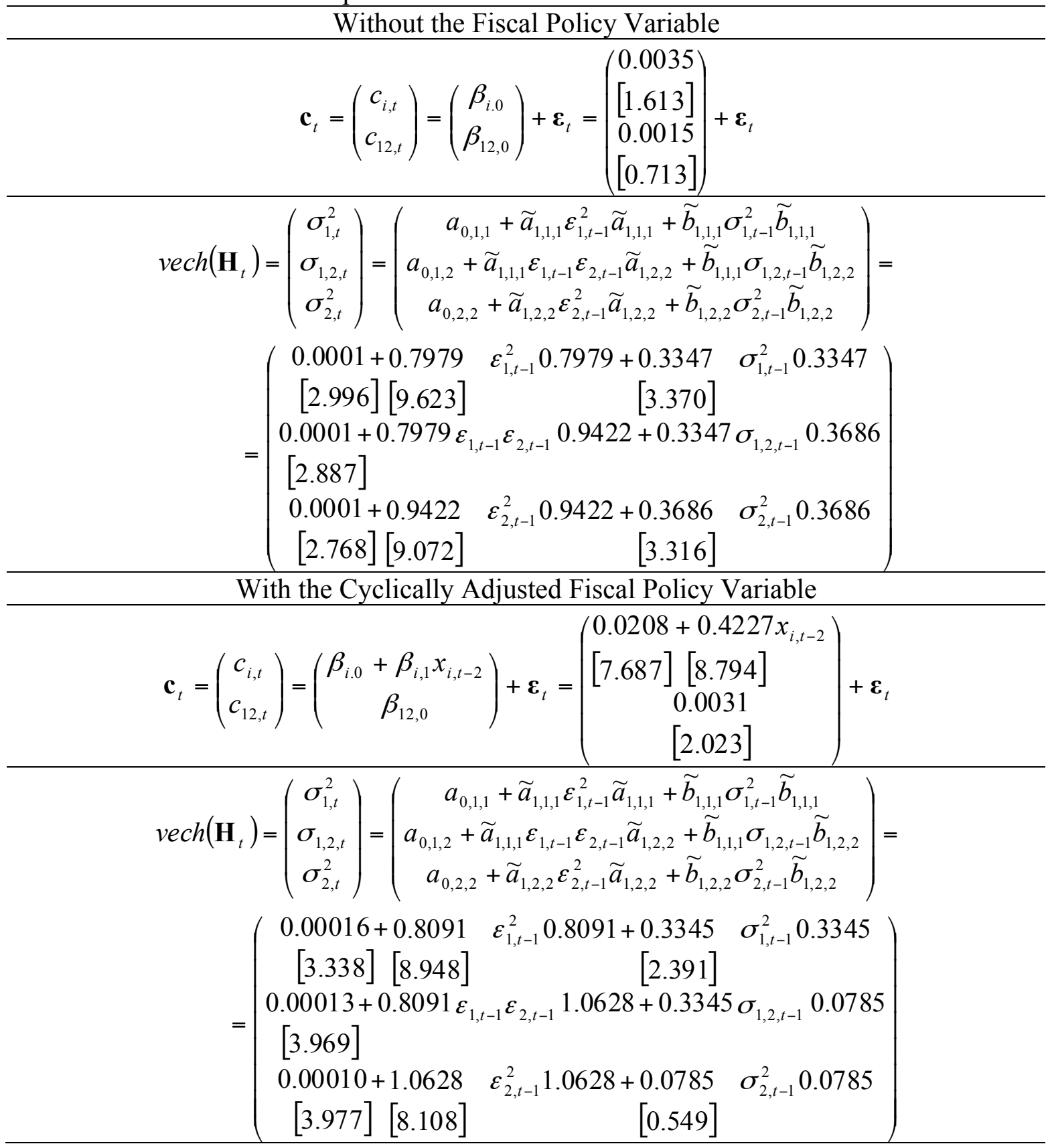


Table 4. Estimated parameters of the Diag-BEKK $(1,1)$ model for Italy. The coefficient to standard error ratios are reported in brackets.

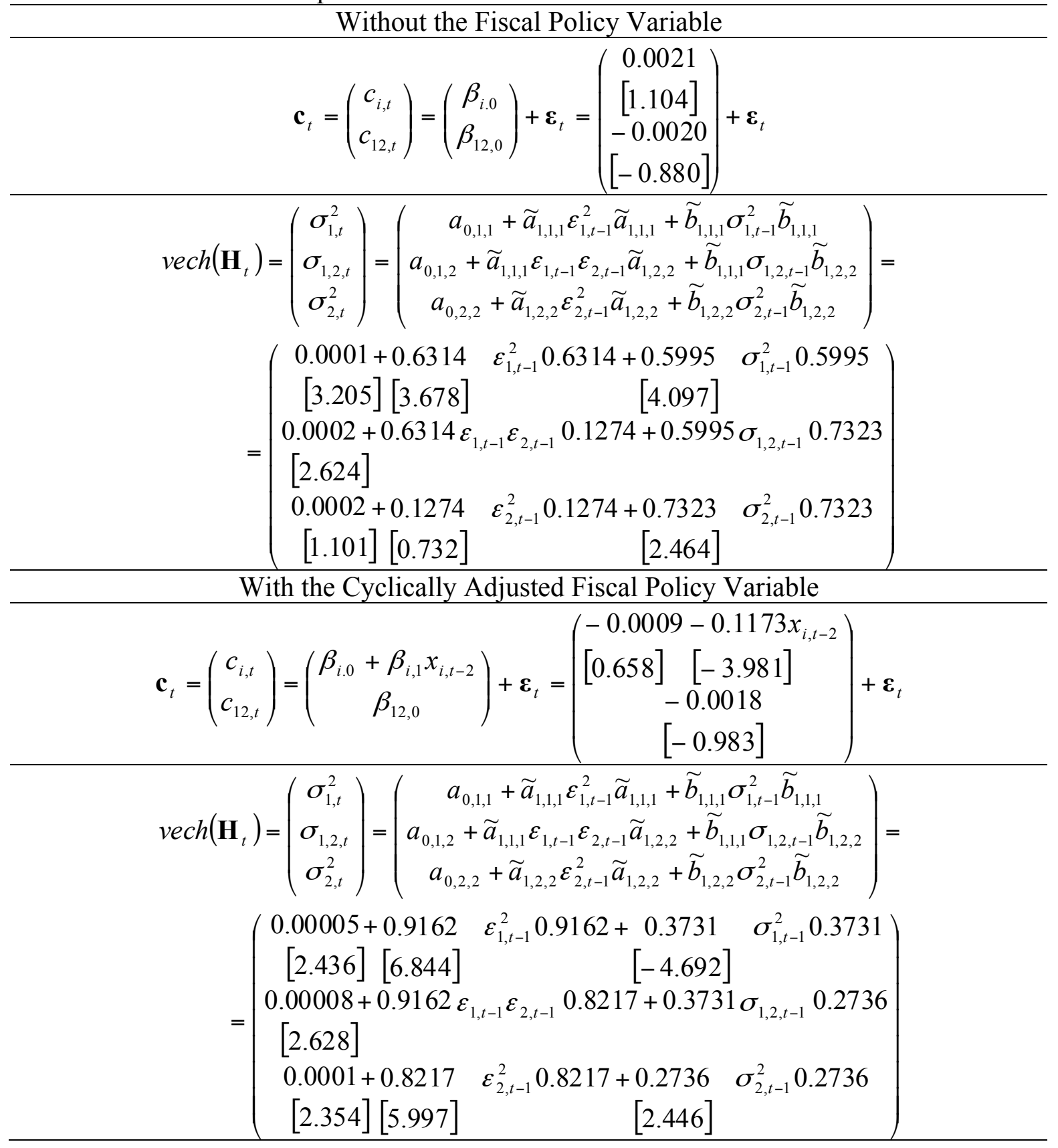


Table 5. Descriptive statistics of $\left(\rho_{i, 12, t}-\rho_{i, 12, t}^{*}\right)$; the percentage impact of the cyclically adjusted fiscal deficit on the time varying business cycle synchronisation.

\begin{tabular}{lrrrr}
\hline Country & Mean & Maximum & Minimum & Std. Dev. \\
\hline Austria & 0.5426 & 25.2452 & -21.1027 & 9.8239 \\
Belgium & 1.4036 & 21.1531 & -3.8198 & 5.7992 \\
Finland & 9.9194 & 68.1599 & -68.7512 & 30.4105 \\
France & -3.5220 & 30.0601 & -36.5187 & 14.6396 \\
Germany & -2.3565 & 87.1816 & -55.4394 & 24.5987 \\
Greece & 9.9220 & 151.1152 & -46.6216 & 40.4158 \\
Ireland & 0.6481 & 65.2331 & -39.6497 & 22.3510 \\
Italy & 11.1891 & 95.3999 & -37.1065 & 28.1504 \\
Netherlands & -0.8652 & 33.9655 & -42.1086 & 16.4292 \\
Portugal & -8.8455 & 28.7667 & -77.2819 & 22.6602 \\
\hline
\end{tabular}

